\title{
Pasture trees in tropical México: the effect of soil nutrients on seedling growth
}

\author{
José Luis Martínez-Sánchez \\ Department of Biological Sciences, University of Stirling, Scotland FK9 4LA. \\ Present address: División Académica de Ciencias Biológicas, Universidad Juárez Autónoma de Tabasco, km 0.5 Carr. \\ VHS-Cardenas, Villahermosa, Tab. México; jlmart@cicea.ujat.mx
}

Received 31-V-2002. C Corrected 05-VIII-2005. Accepted 09-XII-2005.

\begin{abstract}
Environment and seedling community under isolated trees in pastures are different from those in the open pasture. The effect of the pasture trees on the soil nutrients and on the seedling growth were investigated. Seven isolated trees and eight plots were selected in two pastures of 12-yr and 32-yr old derived from a lowland

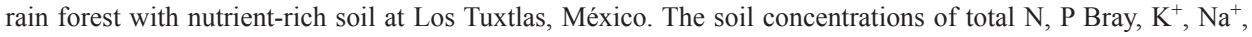
$\mathrm{Ca}^{2+}$ and $\mathrm{Mg}^{2+}$, plus others physical and chemical characteristics, were compared between the pasture trees and the open -pasture. An experiment was done to test the hypothesis that soil from under the pasture trees was better for seedling growth than soil from the open pasture. Seedlings of two native tree species and two domesticated species were grown in soil from the two different sites in a shade-house. The dry weight of the shoot and root/ shoot ratio were compared. Only total $\mathrm{N}, \mathrm{P}$ and $\mathrm{Na}^{+}$differed slightly in concentrations between the sites, but did not promote more seedling biomass. It seems that the soil at this location is sufficiently nutrient-rich even in the open pastures and over-ride any effect of the pasture trees on nutrient availability. Rev. Biol. Trop. 54(2): 363-370. Epub 2006 Jun 01.
\end{abstract}

Key words: isolated trees, Los Tuxtlas, remnant trees, tropical rain forest.

The landscape at Los Tuxtlas, México is characterised by a mosaic of forest fragments, and pastures with isolated remnants of forest trees and tree lines as living fences for pasture boundaries. Pasture trees are left for shade for cattle and people, and for timber when it is of economic value. Native tree density in the pastures ranges from three to eight trees per hectare and their height ranges up to about $40 \mathrm{~m}$ (Guevara et al. 1992).

Studies on abandoned pastures have included pasture trees as sites for natural tree seedling establishment and forest regeneration (Kellman 1979, 1985, McDonnell and Stiles 1983, Guevara et al. 1986, Guevara et al. 1992). Many studies on pasture trees in the tropics have been done in savannas -which have many microclimatic similarities with grasslands at Los Tuxtlas- and have described that pasture trees provide a better overall physical environment for seedling establishment (Kellman 1979, Belsky et al. 1989). Soils under pasture tree canopies have less light, more equable temperatures and higher fertility compared to the open savanna (Isichei and Moughalu 1992, Mordelet et al. 1993, Belsky 1994). Higher surface-soil nutrient concentrations are expected under the trees than in the open pastures since tree crowns protect the soil from leaching, promote nutrient throughfall, and there is a redistribution of nutrients from lower soil horizons through litterfall (Baillie 1989, Grubb 1989). Also there is a common practice among the land owners of cutting the under-crown vegetation and leaving it in place (Guevara et al. 1992). Soil under pasture trees 
has been found to be richer than from open pastures (Radwanski and Wickens 1967, Kellman 1979, Puerto and Rico 1988, Belsky et al. 1989, Weltzin and Coughenour 1990, Isichei and Moughalu 1992, Mordelet et al. 1993, Belsky 1994). As distance from the trunks increased into the open grassland of a pasture in Wisconsin, soil moisture and nutrients decreased, and plant composition differed (Ko and Reich 1993). Cattle faeces and urine also increase soil nutrient concentrations (Parsons 1976). Harper (1977) reported a higher soil moisture and fertility in abandoned livestock corrals, which resulted in accelerated seedling emergence, and enhanced survivorship and growth of Acacia tortilis seedlings, compared to those in the adjacent open savanna.

In this study, the soil-chemistry factor was explored addressing the following question. Are soil nutrient concentrations themselves responsible for more seedling growth under pasture trees than in open pasture? The soil nutrient concentrations under pasture trees were compared to those from the open pasture. In addition, the effect on plant growth, was evaluated growing native and crop plants in a shade-house with the soil from the two different conditions. It was hypothesised that soil nutrient concentrations would be higher under the pasture trees, which in turn would promote higher seedling growth.

\section{MATERIALS AND METHODS}

Study site. The study was located near the Biological Station "Estación de Biología Los

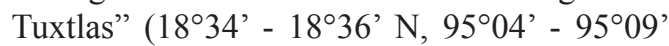
W) (henceforth referred to as LT), at the northern limit of the Los Tuxtlas volcanic field in the State of Veracruz, México (Fig. 1). LT is a natural forest reserve belonging to the Universidad Nacional Autónoma de México. The original vegetation in the region is a Tropical Lowland Evergreen Rain Forest (sensu Whitmore 1984). The Los Tuxtlas volcanic field lies over alkaline-basaltic rocks erupted in two series, the older from 1 and 3 million years ago, and the younger from about 800000 years ago (Nelson and González-Caver 1992). The pastures selected in this study lie on the older series. The last eruptions of Volcán San Martin were in 1664 and 1793 (Friedlaender and Sander 1923 in Martin-Del Pozzo 1997). Eruptions have been mostly of the strombolian type, producing significant quantities of ash and a small volume of lava flows (Nelson and González-Caver 1992). Soils are classified as well drained, coarsetextured, vitric Andosols mixed with volcanic ash (Anonymous 1975). Surface $(0-10 \mathrm{~cm})$ soil in the undisturbed forest is relatively nutrient-rich. It has a clay to clay/loamy texture, a $\mathrm{pH}_{\mathrm{H} 20}$ of $6.9,0.5 \%$ of total nitrogen, $4.2 \mathrm{ig} \mathrm{g}^{-1}$ of extractable phosphorus, $0.63 \mathrm{cmol}_{\mathrm{c}} \mathrm{kg}^{-1}$ of $\mathrm{K}^{+}, 0.55$ of $\mathrm{Na}^{+}, 14.2$ of $\mathrm{Ca}^{2+}, 8.6$ of $\mathrm{Mg}^{2+}, 0.3$ of $\mathrm{H}^{+}$and $0.14 \mathrm{cmol}_{\mathrm{c}} \mathrm{kg}^{-1}$ of $\mathrm{Al}^{3+}$ (MartínezSánchez 2003, 2005). The mean annual temperature at the LT is $25.1^{\circ} \mathrm{C}$. Evaporation at Sontecomapan ( $c a .10 \mathrm{~km}$ SE from LT) had an annual mean of $1390 \mathrm{~mm}$ (1976-1997). Mean annual rainfall is $4487 \mathrm{~mm}$ (with a gap of three years). Months with lowest rainfall are February (261 mm), March (115 mm), April (97.5 mm), and May (105 mm) (Biological Station unpublished data).

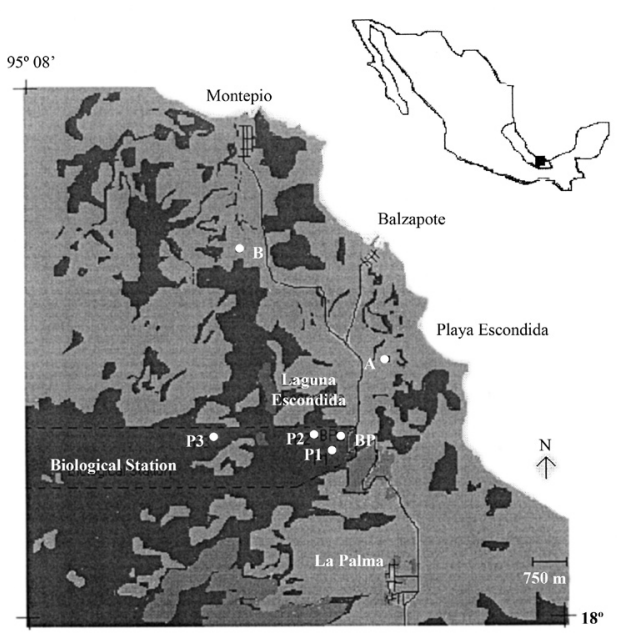

Fig. 1. Location of the study site. Biological Station 'Los Tuxtlas', the buildings (BP), 12-yr old pasture (A), and 32-yr old pasture (B). Dark shading indicates undisturbed forest. 
Site description. Pastures of the region show a very diverse management with many possible sources of variation. Pastures with the least variation were selected for the present study, and they were of different ages (12 $\mathrm{yr}$ and around $32 \mathrm{yr}$ after forest clearance). The 12-yr old pasture is 15 ha and located on hilly terrain between 1.5 and $2 \mathrm{~km} \mathrm{NE}$ of the LT (Fig. 1). The pasture is about $0.5 \mathrm{~km}$ from the sea at $80 \mathrm{~m}$ altitude, and $200 \mathrm{~m}$ downward from a forest fragment. The forest was cut and burned in 1985. For $6 \mathrm{yr}$ the site was under maize (when herbicides were used) or fallow, and for another $6 \mathrm{yr}$ it was used as a pasture. Cattle density was between one (dry season) and three (wet season) cows ha-1. The 32-yr old pasture is about $3.5 \mathrm{~km} \mathrm{~N}$ of the LT (Fig. 1). The pasture is 20 ha and is $30 \mathrm{~m}$ in altitude. For most of the time it has been pasture without any fallow and burning. In 1997 the pasture had 1 to 5 cows ha ${ }^{-1}$ depending on the season and the grass species. Both pastures were of a known history, grazed by a mixture of Swiss and Zebu cattle used for milk and beef production, and had no fertilisers ever applied. The native grass Paspalum conjugatum Beguis, and the African grass Cynodon plectostachyus Pilger dominated the vegetation of the two pastures along with Hyptis atrorubens Poit. Mimosa pudica L. was conspicuous in the 32-yr old pasture.

In each pasture, four $40 \mathrm{~m} \mathrm{x} 40 \mathrm{~m}$ plots were marked, which will be referred to as open pasture. The plots were located in order to represent the topography of the pastures, and were divided into 16 subplots $(10 \mathrm{~m} \mathrm{x}$ $10 \mathrm{~m}$ ) to conduct stratified random sampling. In the 12-yr pasture the plots were set up on a hill top, slope and depression. In the 32-yr pasture, two plots were located on relatively flat ground, and two on a slope. Within or between the study plots, three and four native trees were selected in the 12-yr and 32-yr old pastures, respectively (Table 1).

The frequency of the life-forms (grasses, other herbs, tree and climber seedlings) of the pasture vegetation was obtained, using 4- $\mathrm{m}^{2}$ quadrats in stratified random sampling. The frequency was expressed as the proportion of quadrats in which a particular life-form was present. In each pasture, 11 quadrats were sampled under the trees and 12 in the open pasture.

Soil analysis. Using a $100-\mathrm{ml}$ soil corer (8-cm diameter), during May and October 1996, seven soil samples per plot, and three beneath the canopy of each tree, were collected with stratified random sampling to a depth of $10 \mathrm{~cm}$, for chemical and physical analyses. Samples were collected beneath the trees at 1, 2 and $4 \mathrm{~m}$ from the trunks. Samples were sun-dried for $8 \mathrm{hr}$, sieved through a $1.2-\mathrm{mm}$ mesh, and then stored in polythene bags at $20^{\circ} \mathrm{C}$ for about one year until laboratory analysis. For bulk density analysis, samples were

TABLE 1

Species and size of the trees selected in the pastures

\begin{tabular}{|c|c|c|c|c|}
\hline Pasture age (yr) & Species & Family & $\begin{array}{l}\text { Height } \\
\text { (m) }\end{array}$ & $\begin{array}{l}\mathrm{DBH} \\
(\mathrm{cm})\end{array}$ \\
\hline \multirow[t]{3}{*}{12} & Brosimum alicastrum Sw. & Moraceae & 27.0 & 102 \\
\hline & Pouteria sapota (Jacq.) H. Moore et Stearn & Sapotaceae & 30.0 & 59 \\
\hline & Spondias radlkoferi Donn. Sm. & Anacardiaceae & 25.0 & 69 \\
\hline \multirow[t]{4}{*}{32} & Bursera simaruba (L.) Sarg. & Burseraceae & 22.6 & 52 \\
\hline & Ceiba pentandra Gaertn. & Bombacaceae & 30.1 & 113 \\
\hline & Ficus sp. 1, Ficus sp. 2 (stranglers)* & Moraceae & 12.7 & 98 \\
\hline & Platymiscium pinnatum (Jacq.) Dugand & Fabaceae & 21.3 & 50 \\
\hline
\end{tabular}

\footnotetext{
* The Ficus stranglers were fused and only the combined diameters could be measured.
} 
oven-dried at about $95^{\circ} \mathrm{C}$ to a constant weight and weighed to obtain the dry weight per unit volume $\left(\mathrm{g} \mathrm{cm}^{-3}\right)$. Since drying temperature was not $105^{\circ} \mathrm{C}$, bulk density values could be slightly overestimated.

Soil analyses were done at the Instituto de Geología of the Universidad Nacional Autónoma de México. Analyses were all done in duplicate and checked with international standards. $\mathrm{pH}$ was determined in $\mathrm{H}_{2} \mathrm{O}(1: 2.5)$ and in a $1 \mathrm{M} \mathrm{KCl}(1: 2.5)$ solution. Total nitrogen and extractable phosphorus were analysed. For total $\mathrm{N}$ the samples were digested with sulphuric acid, distilled in boric acid and determined by titration with $0.1 \mathrm{M} \mathrm{H}_{2} \mathrm{SO}_{4}$ (the Kjeldahl method). Phosphorus was extracted with $0.025 \mathrm{M} \mathrm{HCl}$ and $0.03 \mathrm{M} \mathrm{NH}_{4} \mathrm{~F}$ and determined by photocolorimetry at $660 \mu \mathrm{m}$. Exchangeable cations were extracted in $1 \mathrm{M}$ ammonium acetate and centrifuged for $5 \mathrm{~min}$ at $2500 \mathrm{rpm}$. Exchangeable $\mathrm{Ca}^{2+}$ and $\mathrm{Mg}^{2+}$ were determined by atomic absorption spectrophotometry in $0.5 \% \mathrm{LaCl}_{3}$ solution, and $\mathrm{K}^{+}$and $\mathrm{Na}^{+}$by flame photometry in a $\mathrm{CaCl}_{2}$ solution. Exchangeable $\mathrm{Al}^{3+}$ and $\mathrm{H}^{+}$ions were determined by titration with $0.01 \mathrm{M} \mathrm{NaOH}$ in a solution of $1 \mathrm{M} \mathrm{KCl}$. Cation exchange capacity (CEC) was assessed by the summation of exchangeable cations. Soil texture was determined by a hydrometry technique (Bouyoucos 1963), and the soils were not completely dried according to the method for Andosols (Silvia Sánchez, pers. comm.).

Seedling growth experiment. During July 1996 seeds of two native, light-demanding tree species (Cordia megalantha S.F. Blake and Inga sinacae M. Sousa \& Ibarra Manríquez) and of two crop species (maize, Zea mays L.; and beans, Phaseolus vulgaris L.) were used. Seeds with damage, fungus or insect predation were discarded. Soils from the top $10 \mathrm{~cm}$ of the two pastures, both under the pasture trees and in the open, were collected randomly within the plots and bulked for each plot without sieving. Nursery pots $(15 \times 25 \mathrm{~cm})$ were filled with the soil and the seeds allowed to germinate. Each pot was placed in a separate tray in a shade-house located outside the forest, which was made with a green nylon-mesh $(1.2 \mathrm{~mm})$ that allowed in rain water and fresh air. The trays were watered with previously collected rain water when required, and randomly relocated every 20-30 days to minimize border effects. Five pots (replicates) with five seeds each were used for each species and soil type (treatment). Germination took less than 50 days for all species. After 30-90 days, depending on the time that took for the species to reach a height of $20 \mathrm{~cm}$, the seedlings were thinned to one per pot in order to avoid a competition effect by seedlings density onwards. The more robust seedlings with the best appearance were left in and allowed to grow. A pesticide (Carbofuran) at a concentration of $1 \mathrm{ml} \mathrm{l}^{-1}$ of water was applied to the seedlings three times from October 1996 onwards to control herbivory, chiefly in Inga sinacae. All seedlings of the same species were harvested at the same time. Seedling age at time of harvest (about $50 \mathrm{~cm}$ in height) was two months for maize and beans, four months for Cordia megalantha, and eight months for Inga sinacae. A second set of seeds was possible to sown for maize and beans (Maize ${ }^{2}$ and Beans ${ }^{2}$ ). Several seeds and seedlings were lost owing to mice, insects, and overheating by the black plastic pots, reducing the final sample size of seedlings up to seven. Seedlings were dried at $40^{\circ} \mathrm{C}$ for 7-30 days depending on their weight. A correction factor was applied from a sample oven-dried at $95^{\circ} \mathrm{C}$ to constant weight. The dry weight was obtained for shoots and roots for each seedling, and comparisons were done on total weight and root/shoot weight ratio.

Statistical analyses were done with Statgraphics Plus 2.0. For the soil analyses, replicates were three pasture-trees in the $12-\mathrm{yr}$ pasture and four in the 32-yr pasture, and four open-pasture plots in each pasture. The value of the trees' replicate was obtained from the average of the three field soil samples per tree. The value of the plots' replicate was obtained from the average of the seven field samples per plot. For the seedling growth experiment, replicates were five seedlings for each soil condition and 
species treatment. In order to minimize the possible effect of pasture age, a two-way ANOVA was conducted considering only the analysis of the site factor (Zar 1998).

\section{RESULTS}

Frequency (percentage of occurrence from the total number of $4-\mathrm{m}^{2}$ quadrats) of the herb species was $100 \%$ in the open pastures and under the trees. The frequency of tree and climber seedlings were lower in the open pasture $(30.0 \%$ and $50.0 \%$ respectively) than under the trees $(80.6 \%$ and $90.3 \%)$. There were 37 plant species in the open-pasture quadrats $\left(96 \mathrm{~m}^{2}\right)$ but 49 under the pasture trees $\left(88 \mathrm{~m}^{2}\right)$, including two unidentified taxa. There were only six forest tree species as seedlings in the open pastures but 17 under the pasture trees. The vegetation under the pasture trees had more plant species, and three times more forest species, than the open pasture.

Although not significantly $(p=0.08)$, soil bulk density from the pasture trees $\left(0.9 \mathrm{~g} \mathrm{~cm}^{-3}\right)$ was lower than from the open pasture $\left(0.98 \mathrm{~g} \mathrm{~cm}^{-3}\right)$. The soil under the pasture trees showed higher concentrations of total $\mathrm{N}$ and $\mathrm{Na}^{+}$than the open pasture, while the opposite was found for P. ANOVA results with $d f=3$ were as follows: $F=12.5, p=$ $0.001\left(\right.$ total N), $F=11.38, p=0.001\left(\mathrm{Na}^{+}\right)$, $F=5.65, p=0.05$ (P) (Table 2). Soil under the trees had more silt than from the open pasture $(d f=3, F=8.5, p=0.01)$. No difference was found in seedling growth between the soil from the open pastures and the soil under the trees (Beans1, $t=0.98, p=0.59$; Beans2, $t=0.02$, $p=0.94$; Maiz1, $t=1.68, p=0.11$; Maiz2, $t=0.03, p=0.87 ;$ I. sinacae, $t=1.55, p=0.2$; $C$. megalantha, $t=0.98, p=0.68)$. Seedlings root/shoot ratio was higher with the soil from

TABLE 2

Mean \pm S.D. of soil characteristics from underneath pasture trees and open pastures (OP) of two ages at Los Tuxtlas, Mexico

\begin{tabular}{|c|c|c|c|c|c|c|}
\hline & 12-yr Trees & 32-yr Trees & $12-y r$ OP & $32-y r$ OP & Tree Means & OP Means \\
\hline $\mathrm{n}$ & 3 & 4 & 4 & 4 & 7 & 8 \\
\hline Clay (\%) & $29.0 \pm 4.9$ & $39.4 \pm 4.9$ & $28.3 \pm 3.7$ & $34.3 \pm 6.3$ & $35.0 \pm 4.9$ & $31.3 \pm 5.0$ \\
\hline Silt (\%) & $39.1 \pm 2.1$ & $25.4 \pm 1.1$ & $40.9 \pm 1.8$ & $38.5 \pm 1.0$ & $31.8^{2} \pm 1.5$ & $39.7^{2} \pm 1.5$ \\
\hline Sand $(\%)$ & $31.9 \pm 6.3$ & $35.2 \pm 6.3$ & $30.7 \pm 3.8$ & $27.2 \pm 5.9$ & $33.2 \pm 6.3$ & $29.0 \pm 4.5$ \\
\hline $\mathrm{pH}_{\mathrm{H} 2 \mathrm{O}}$ & $7.26 \pm 0.2$ & $6.47 \pm 0.2$ & $7.15 \pm 0.1$ & $6.74 \pm 0.1$ & $6.9 \pm 0.2$ & $6.9 \pm 0.1$ \\
\hline $\mathrm{H}_{\mathrm{KCl}}$ & $5.92 \pm 0.3$ & $5.14 \pm 0.3$ & $5.82 \pm 0.2$ & $5.25 \pm 0.2$ & $5.55 \pm 0.3$ & $5.55 \pm 0.2$ \\
\hline Total N (\%) & $0.42 \pm 0.03$ & $0.45 \pm 0.03$ & $0.37 \pm 0.01$ & $0.37 \pm 0.01$ & $0.43^{1} \pm 0.03$ & $0.37^{1} \pm 0.01$ \\
\hline Ext. $P\left(\mu g g^{-1}\right)$ & $4.83 \pm 0.3$ & $1.29 \pm 0.3$ & $12.8 \pm 6.9$ & $1.11 \pm 0.2$ & $3.46^{3} \pm 0.3$ & $8.13^{3} \pm 4.2$ \\
\hline $\mathrm{K}^{+}\left(\mathrm{cmol}_{\mathrm{c}} \mathrm{kg}^{-1}\right)$ & $1.12 \pm 0.02$ & $0.51 \pm 0.02$ & $1.24 \pm 0.02$ & $0.56 \pm 0.03$ & $0.8 \pm 0.02$ & $0.83 \pm 0.02$ \\
\hline $\mathrm{Na}^{+}\left(\mathrm{cmol}_{\mathrm{c}} \mathrm{kg}^{-1}\right)$ & $0.59 \pm 0.01$ & $0.53 \pm 0.01$ & $0.46 \pm 0.005$ & $0.32 \pm 0.005$ & $0.56^{1} \pm 0.01$ & $0.39^{1} \pm 0.005$ \\
\hline $\mathrm{Ca}^{2+}\left(\mathrm{cmol}_{\mathrm{c}} \mathrm{kg}^{-1}\right)$ & $10.9 \pm 0.7$ & $9.5 \pm 0.7$ & $13.8 \pm 1.25$ & $7.67 \pm 0.55$ & $10.1 \pm 0.7$ & $9.9 \pm 0.8$ \\
\hline $\mathrm{Mg}^{2+}\left(\mathrm{cmol}_{\mathrm{c}} \mathrm{kg}^{-1}\right)$ & $5.8 \pm 1.35$ & $9.9 \pm 1.35$ & $7.1 \pm 0.7$ & $8.08 \pm 0.6$ & $7.8 \pm 1.3$ & $7.6 \pm 0.6$ \\
\hline $\mathrm{H}^{+}\left(\mathrm{cmol}_{\mathrm{c}} \mathrm{kg}^{-1}\right)$ & $0.20 \pm 0.1$ & $0.32 \pm 0.1$ & $0.18 \pm 0.04$ & $0.21 \pm 0.03$ & $0.26 \pm 0.1$ & $0.2 \pm 0.03$ \\
\hline $\mathrm{Al}^{3+}\left(\mathrm{cmol}_{\mathrm{c}} \mathrm{kg}^{-1}\right)$ & $0.05 \pm 0.003$ & $0.21 \pm 0.03$ & $0.05 \pm 0.003$ & $0.15 \pm 0.01$ & $0.12 \pm 0.03$ & $0.1 \pm 0.01$ \\
\hline CEC $\left(\mathrm{cmol}_{\mathrm{c}} \mathrm{kg}^{-1}\right)$ & $18.7 \pm 2.2$ & $21.0 \pm 2.2$ & $22.8 \pm 2.0$ & $17.0 \pm 1.2$ & $20.0 \pm 2.0$ & $20.1 \pm 1.1$ \\
\hline Bulk density $\left(\mathrm{g} \mathrm{cm}^{-3}\right)$ & $0.96 \pm 0.1$ & $0.82 \pm 0.1$ & $0.96 \pm 0.04$ & $1.0 \pm 0.03$ & $0.9 \pm 0.1$ & $0.98 \pm 0.03$ \\
\hline
\end{tabular}

Significant differences between right columns (italics) are indicated with: ${ }^{1} p<0.001,{ }^{2} p<0.005,{ }^{3} p<0.05$. 
TABLE 3

Means comparisons of total dry weight $(g)$ and root/shoot dry weight $(g)$ ratio of seedlings growing with soil from underneath pasture trees and open pasture (OP)

\begin{tabular}{|c|c|c|c|c|c|c|c|}
\hline & & & & & & Root & atio \\
\hline & & Trees & OP & $p$ & Trees & OP & $p$ \\
\hline & $\mathrm{n}$ & 7 & 10 & & 7 & 10 & \\
\hline Beans $^{1}$ & Mean & 3.25 & 3.24 & 0.59 & 0.223 & 0.148 & 0.15 \\
\hline & S.E. & 1.1 & 0.69 & & 0.06 & 0.02 & \\
\hline Beans $^{2}$ & Mean & 1.44 & 1.48 & 0.94 & 0.13 & 0.126 & 0.93 \\
\hline & S.E. & 0.18 & 0.26 & & 0.013 & 0.01 & \\
\hline Maíz ${ }^{1}$ & Mean & 1.39 & 0.98 & 0.11 & 0.204 & 0.216 & 0.72 \\
\hline & S.E. & 0.206 & 0.131 & & 0.031 & 0.031 & \\
\hline Maíz ${ }^{2}$ & Mean & 5.23 & 5.62 & 0.87 & 0.27 & 0.22 & 0.03 \\
\hline & S.E. & 1.04 & 0.91 & & 0.02 & 0.01 & \\
\hline & $\mathrm{n}$ & 7 & 8 & & 7 & 8 & \\
\hline I. sinacae & Mean & 3.87 & 5.88 & 0.2 & 0.34 & 0.22 & 0.05 \\
\hline & S.E. & 0.87 & 1.24 & & 0.06 & 0.02 & \\
\hline C. megalantha & Mean & 1.62 & 1.82 & 0.68 & 0.14 & 0.19 & 0.31 \\
\hline & S.E. & 0.25 & 0.26 & & 0.025 & 0.02 & \\
\hline
\end{tabular}

Significant results are highlighted.

the pasture trees than with the soil from the open pasture only in $Z$. mays $(t=6.1, p=0.03)$ and $I$. sinacae $(t=4.9, p=0.05)$ (Table 3$)$.

\section{DISCUSSION}

Like Guevara et al. (1992), more woody species were found under the pasture trees than in the open pastures. As expected (Mordelet et al. 1993), the soil under the pasture trees had a lower bulk density than that of the open pastures despite the high trampling, possibly because of the effect of the organic matter from the cattle droppings and a higher surface soil moisture.

Litterfall seems to affect soil chemistry underneath the trees (Baillie 1989, Grubb 1989), such that it is expected that different tree species could cause different effect. However, soil nutrient concentrations underneath four trees of Mangifera indica L. did not show lower coefficients of variation to those found in the present study from trees of various species (Martínez-Sánchez 1999).

The higher seedling density and diversity found under the tree canopies than in the open pasture depend to a large extent on the seed rain, seed germination, and seedling establishment (Guevara et al. 1992, Holl 1999) which should be tested with specific kinds of experiments. The variable of seedling growth, which was studied herein, did not show significant differences between the soils from the two different sites.

Only total $\mathrm{N}$ and $\mathrm{Na}^{+}$showed the expected trends of higher concentrations under the pasture trees than in open pastures, however shoot growth with soil from under the trees was not significantly better (Beans $1, t=0.98$, $p=0.59$; Beans2, $t=0.02, p=0.94$; Maiz1, $t=1.68, p=0.11$; Maiz2, $t=0.03, p=0.87$; 
I. sinacae, $t=1.55, p=0.2 ; C$. megalantha, $t=0.98, p=0.68)$. N, $\mathrm{P}$ and $\mathrm{K}$ are well known as the chief limiting nutrients for plant growth. Perhaps higher concentrations of total $\mathrm{N}$ itself, when $\mathrm{P}$ and $\mathrm{K}$ are not limited like in this case, are not sufficient to promote higher growth. Nutrient concentrations between the two types of microsites at this location were not strikingly different and, even in the open pastures, concentrations (including $\mathrm{P}$ and $\mathrm{K}^{+}$) were high enough to avoid growth limitation of the shoot in all species tested. Crops (e.g. maize) are known to demand high amounts of these nutrients and might be expected to respond faster to nutrient addition (Luizão 1995). By contrast wild species are more efficient in the use of the soil resource and do not respond equally to nutrient addition (Chapin 1980). Holl (1999) did not find any noticeable difference on tree seedling growth between forest soils having higher nutrient concentrations, and pasture soils. She found that microclimatic factors like soil moisture, temperature, and solar radiation in the pastures, were important to forest recovery, and seed dispersal seemed to be the primary factor. Pasture trees seem to be more important as seed foci for forest recovery rather than as providers of soil nutrients.

Plants tend to have a higher root/shoot ratio at low soil nutrient concentrations as a response to acquire more nutrients (Marschner 1995). High root/shoot ratios would be associated with nutrient-poor soils and low ratios with nutrientrich soils. In this study, no evidence was found of higher soil nutrient concentrations under the trees (lower root/shoot ratios under the trees) (Table 3). By contrast, two species (Zea mays and Inga sinacae) had a higher root/shoot ratio in soils from under the trees, indicating a possible lower $\mathrm{P}$ concentration in these sites. Overall, low values of root/shoot ratios were found, possibly owing to the nutrient-rich condition of the soil.

The study concludes that the establishment of open pasture at this location do not cause a major effect on soil nutrient concentrations, which was supported by the seedling growth experiment. It seems that the presence of isolated trees in the pasture do not improve soil nutrient conservation at this location.

\section{ACKNOWLEDGMENTS}

I thank John Proctor and five anonymous reviewers for their corrections. Thanks to Silvia Sánchez for the soil analyses. I thank also the owner Luis Juan Argüelles at Balzapote for lending me his pastures. This study was part of my $\mathrm{Ph}$. D. thesis funded by CONACYT and SEMARNAP at México.

\section{RESUMEN}

Los árboles aislados de los pastizales presentan un micro ambiente y comunidad de plántulas diferente a los del pastizal abierto. Se investigó el efecto de los árboles aislados en los nutrientes del suelo y en el crecimiento de plántulas. Se seleccionaron siete árboles aislados y ocho parcelas en dos pastizales de 12 y 32 años de edad, originados del cambio de uso de suelo de selva húmeda tropical con un suelo fértil, en Los Tuxtlas, México. Se compararon varias características físicas y químicas del suelo de los árboles y el pastizal abierto, así como las concentraciones de $\mathrm{N}$ total, $\mathrm{P}$ Bray, $\mathrm{K}^{+}, \mathrm{Na}^{+}, \mathrm{Ca}^{2+}$ y $\mathrm{Mg}^{2+}$. Se realizó un experimento para probar la hipótesis de que el suelo bajo los árboles aislados era mejor para el crecimiento de plántulas que el suelo del pastizal abierto. En un invernadero con suelo de los dos sitios diferentes, se pusieron a crecer plántulas de dos especies de árboles nativos y dos especies domesticadas. Se comparó el peso seco de la porción aérea de las plántulas y del cociente raíz/porción aérea. Solo difirieron ligeramente las concentraciones en suelo de $\mathrm{N}$ total, $\mathrm{P}$ y $\mathrm{Na}^{+}$entre los sitios, pero estas no produjeron una mayor biomasa en las plántulas. Aparentemente el suelo en esta localidad es lo suficientemente rico en nutrientes aún en el pastizal abierto y opaca cualquier efecto de los árboles aislados del pastizal en la disponibilidad de nutrientes.

Palabras clave: árboles aislados, remanentes, Los Tuxtlas, selva húmeda tropical.

\section{REFERENCES}

Anonymous. 1975. Soil maps of the world. Vol. III. México and Central América. FAO/UNESCO, Paris.

Baillie, I.C. 1989. Soil characteristics and classification in relation to the mineral nutrition of tropical wooded ecosystems, p. 15-26. In J. Proctor (ed.). Mineral 
nutrients in tropical forest and savanna ecosystems. BES Special publ. No. 9, Blackwell, Oxford, England.

Belsky, A.J. 1994. Influences of trees on savanna productivity: tests of shade, nutrients, and tree-grass competition. Ecology 75: 922-932.

Belsky, A.J., R.G. Amundson, J. M. Dexbury, S.J. Riha, A.R. Ali \& S.M. Mwonga. 1989. The effects of trees on their physical, chemical and biological environments in a semi-arid savanna in Kenya. J. Appl. Ecol. 26: 1005-1024.

Boyoucous, G.J. 1963. Directions for making mechanical analyses of soil by hydrometer method. Soil Sci. 42: 25-30.

Chapin, F.S. 1980. The mineral nutrition of wild plants. Annu. Rev. Ecol. Syst. 11: 233-260.

Grubb, P.J. 1989. The role of mineral nutrients in the tropics: a plant ecologist's view. p. 417-439. In J. Proctor (ed.). Mineral nutrients in tropical forest and savanna ecosystems. BES Special publ. No. 9, Blackwell, Oxford, England.

Guevara, S., S.E. Purata \& E. Van der Maarel. 1986. The role of remnant forest trees in tropical secondary succession. Vegetatio 66: 77-84.

Guevara, S., J. Meave del Castillo, P. Moreno-Casasola \& J. Laborde. 1992. Floristic composition and vegetation structure under isolated trees in neotropical pastures. J. Veg. Sci. 3: 655-664.

Harper, J.L. 1977. Population biology of plants. Academic, London, England. 832 p.

Holl, K.D. 1999. Factors limiting tropical rain forest regeneration in abandoned pasture: seed rain, seed germination, microclimate, and soil. Biotropica 31: 229-242.

Isichei, A.O. \& J.I. Muoghalu. 1992. The effects of tree canopy cover on soil fertility in a Nigerian savanna. J. Trop. Ecol. 8: 329-338.

Kellman, M. 1979. Soil enrichment by neotropical savanna trees. J. Ecol. 67: 565-577.

Kellman, M. 1985. Forest seedling establishment in neotropical savannas: transplant experiments of Xylopia frutescens and Calophyllum brasiliense. J. Biogeo. 12: 373-379.

Ko, L.J. \& P.B. Reich. 1993. Oak trees effects on soil and herbaceous vegetation in savannas and pastures in Wisconsin. Amer. Mid Natur. 130: 31-42.
Luizão, F.J. 1995. Ecological studies in contrasting forest types in Central Amazonia. Ph.D. Thesis, University of Stirling, Scotland.

Marschner, H. 1995. Mineral nutrition of higher plants. Academic, London, England. 889 p.

Martin del Pozzo, A.L. 1997. Geología, pp. 25-31. In E. González, R. Dirzo \& R. . Vogt (eds.). Historia natural de Los Tuxtlas. Universidad Nacional Autónoma de México. CONABIO. México.

Martínez-Sánchez, J.L. 1999. Aspects of tropical rainforest and pasture nutrient dynamics at Los Tuxtlas, México. Ph.D. Thesis. University of Stirling, Scotland. $145 \mathrm{p}$.

Martínez-Sánchez, J.L. 2003. The effect of time of use of tropical pastures on soil fertility and cattle productivity. Ecotropicos 16(1): 17-26.

Martínez-Sánchez, J.L. 2005. Nitrogen and phosphorus resorption in a neotropical rain forest of a nutrientrich soil. Rev. Biol. Trop. 53(3): 353-359.

McDonnell, M.J. \& E.W. Stiles. 1983. The structural complexity of old field vegetation and the recruitment of bird dispersed plant species. Oecologia (Berl.) 56: 109-116.

Mordelet, P., L. Abbadie \& J.C. Menaut. 1993. Effects of tree clumps on soil characteristics in a humid savanna of West Africa. Plant and Soil 153: 103-111.

Nelson, S.A. \& E. González-Caver. 1992. Geology and $\mathrm{K}-\mathrm{Ar}$ dating of the Tuxtla volcanic field, Veracruz, México. Bull. Vulc. 55: 85-96.

Parsons, J.J. 1976. Forest to pasture: development or destruction? Rev. Biol. Trop. 24 (Suppl.1): 121-138.

Puerto, A. \& M. Rico. 1988. Influence of tree canopy (Quercus rotundifolia Lam. and Quercus pyrenaica Willd.) on old field succession in marginal areas of Central Western Spain. Acta Oecologica 9: 337-358.

Radwanski, S.A. \& G.E. Wickens. 1967. The ecology of Acacia albida on mantle soils in Zalingei, Jebel Marra, Sudan. J. Appl. Ecol. 4: 569-578.

Weltzin, J.F. \& M.B. Coughenour. 1990. Savanna tree influence on understorey vegetation and soil nutrients in northwestern Kenya. J. Veg. Sci. 1: 325-332.

Whitmore, T.C. 1984. Tropical rain forest of the Far East. Clarendon, Oxford, England. 352 p.

Zar, J.H. 1998. Biostatistical Analysis. Prentice, New Jersey, USA. 929 p. 